\title{
ELECTRODEPOSITION, CHARACTERIZATION AND CORROSION INVESTIGATIONS OF GALVANIC TIN-ZINC LAYERS FROM PYROPHOSPHATE BATHS
}

\author{
Milena D. Stopić ${ }^{a}$, Bernd G. Friedrich ${ }^{b}$ \\ ${ }^{a}$ MEAB Chemie Technik GmbH, Aachen, Germany, \\ e-mail: milena@meab-mx.com, \\ ORCID iD: Dhttp://orcid.org/0000-0002-2877-6236, \\ ${ }^{b}$ IME Process Metallurgy and Metal Recycling, \\ RWTH Aachen University, Germany, \\ e-mail: bfriedrich@ime-aachen.de, \\ ORCID iD: @http://orcid.org/0000-0002-2934-2034
}

FIELD: Chemical Technology, Electrochemistry, Corrosion ARTICLE TYPE:Original Scientific Paper ARTICLE LANGUAGE: English

\section{Summary:}

Tin-zinc alloy deposits are recognised as a potential alternative to toxic cadmium as corrosion resistant coatings. Tin-zinc alloy layers offer outstanding corrosion protection for steel by combining the barrier protection of tin with the galvanic protection of zinc. Tin-zinc coatings have been used on the chassis of electrical and electronic apparatus and on critical automotive parts such as fuel and brake line components. In this study, tin-zinc alloy deposits were successfully prepared from alkaline, pyrophosphate-based electrolytes. The plating process gives a compact and fine grained deposit. The desired proportions of tin and zinc in the deposited alloy are determined by the bath composition and the operating conditions during plating. Three electrode systems were used for the electrochemical investigation. The mechanism of Sn-Zn electrodeposition was studied by linear and cyclic voltammetry. The corrosion parameters, including open-circuit potential-time curves, corrosion potential and corrosion current density of electrodeposited tin-zinc alloys of different compositions have been examined in a brine medium containing $3 \mathrm{wt}$. \% $\mathrm{NaCl}$. The corrosion resistance depends on the plating composition. The Sn-28Zn deposit showed the best anticorrosive properties.

Key words: electrodeposition, corrosion, galvanic layers, zinc, tin. 


\section{Introduction}

Because of outstanding corrosion resistance, tin-zinc layers are mostly used in aerospace, automobile and electrical applications replacing toxic cadmium (Ashiru and Shirokoff, 1996, pp.159-169). The previously used cadmium is not permitted for usage, except for military applications. Additionally, tin-zinc layers have shown excellent solderability and high electrical conductivity.

Because of some disadvantages, the previously mostly used sodium stannate-zinc cyanide plating bath was not widely accepted for industrial applications. In this work, tin-zinc layers were produced in analkaline, noncyanide, pyrophosphate-based bath. This work contains a description of the synthesis of tin-zinc layers, a detailed analysis of the influence of the deposition parameters and the mechanism of synthesis, a morphological characterization of the formed layers and their corrosion stability. The studied electrolyte contains tin sulphate, zinc sulphate, potassium pyrophosphate as a complexing agent and an additive of gelatine. The formation of tin-zinc layers was performed in a Hull cell. At the same time, X-ray fluorescence was used for a chemical analysis of the electrochemically formed layers. The analyses of the corrosion stability via the open-circuit potential-time curves, the corrosion potential and the corrosion current density of the electrodeposited tin-zinc layers with different chemical compositions have been performed in a brine medium containing $3 \mathrm{wt}$. \% $\mathrm{NaCl}$.

The most important aim of this study was to find a relationship between the process-determining parameters and the characteristics of the electrochemically formed Sn-Zn-layers.

The following partial activities were performed:

- Process design and the analysis of the influence of different parameters on the synthesis of $\mathrm{Sn}-\mathrm{Zn}$ layers

- Determination of deposition kinetics as well as the stability (corrosion resistance) of the formed $\mathrm{Sn}-\mathrm{Zn}$ layers

- Investigation of the metal distribution as well as the morphology of layers depending on the chemical composition of the baths used

\section{Synthesis of tin-zinc layers in the Hull cell}

The Hull cells are small transportable electrolytic cells. The simulation of different electrochemical processes was mostly performed in the Hull cell. The investigations of electroplating were performed in a range of current density (Andrle and Jelinek, 2007). As the anode plate and the cathode test panel are placed along the non-parallel sides, it is possible to investigate different current densities at the same time in only one performed experiment (Figure 1). 

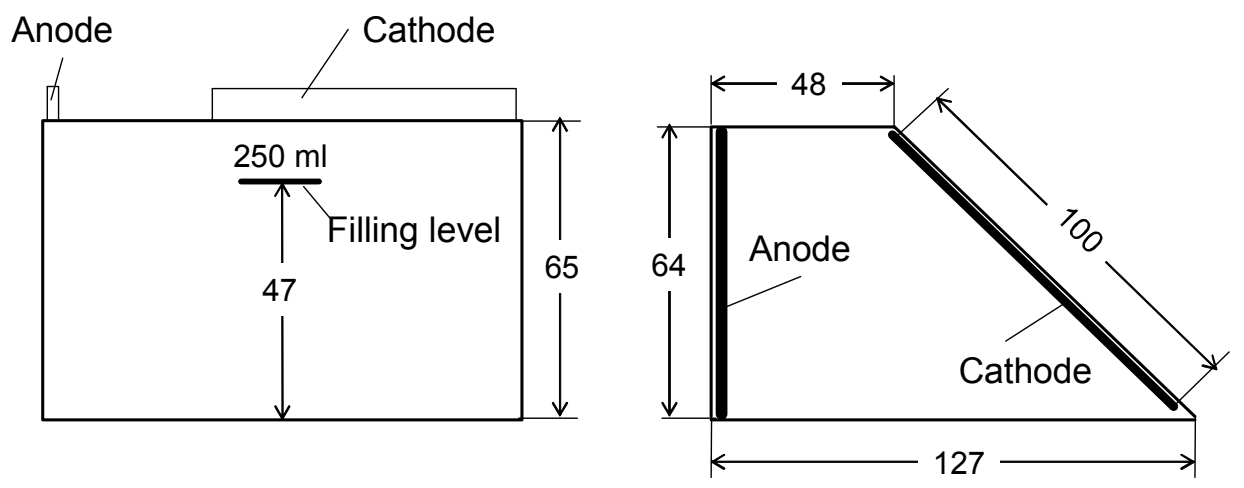

Figure 1 - Principle of work for the Hull cell (Volume of $250 \mathrm{ml}$ ) Puc. 1 - Принцип работы ячейки Хулла(на объем 250 мл) Slika 1 - Princip rada Hulove ćelije (zapremine $250 \mathrm{ml}$ )

The container of the Hull cell consists of a non-conductive material (e.g., Plexiglas). A brass or steel test panel is usually used as a cathode (cathode dimensions: $0.3 \times 70 \times 100 \mathrm{~mm}$ ). The anode material is adjusted to the used electrolyte. As an anode,either a soluble anode based on the material to be coated can be used or an unsoluble anode made from the material such as stainless steel or lead (anode dimensions: $3 \times 70 \times 65 \mathrm{~mm}$ ).

\section{Influence of different parameters on Sn-Zn electroplating}

\section{- Influence of the metal ion concentration}

The concentration of alloying elements in an electrolyte has an important influence on the chemical composition of formed coatings (Despic, \& Jovic, 1996, pp.239-248). The metal ion concentration in a bath can be varied in three different ways (Vitkova, et al. 1996, pp.226-231):

1. Change of the metal ions ratio, in which the total metal content stays constant

2. Change of the total metal content, in which the metal ion ratio stays constant

3. Change of the concentration of one alloying element, in which the concentration of the other element stays constant

The chemical compositions of the baths studied are given in Table 1. 
Table 1 - Variations of the metal and complexing agent concentration in the baths Таблица 1 - Варианты концентрации металлов и сплавов для покрытия ванны Tabela 1 - Varijacije koncentracije metala i kompleksirajućeg sredstva u kupatilima

\begin{tabular}{|c|c|c|c|c|c|c|c|}
\hline \multicolumn{4}{|c|}{ metal content } & \multirow{2}{*}{\multicolumn{2}{|c|}{$\begin{array}{l}\text { total metal content } \\
\qquad \mathrm{Sn}^{2+}+\mathrm{Zn}^{2+}\end{array}$}} & \multirow{2}{*}{\multicolumn{2}{|c|}{$\begin{array}{c}\text { complexing agent } \\
\text { content } \mathrm{P}_{2} \mathrm{O}_{7}^{4-}\end{array}$}} \\
\hline \multicolumn{2}{|c|}{$\mathrm{Sn}^{2+}$} & \multicolumn{2}{|c|}{$\mathrm{Zn}^{2+}$} & & & & \\
\hline$[\mathrm{mol} / \mathrm{l}]$ & {$[\mathrm{g} / \mathrm{l}]$} & {$[\mathrm{mol} / \mathrm{l}]$} & {$[g / l]$} & {$[\mathrm{mol} / \mathrm{l}]$} & {$[\mathrm{g} / \mathrm{l}]$} & {$[\mathrm{mol} / \mathrm{l}]$} & {$[\mathrm{g} / \mathrm{l}]$} \\
\hline \multirow{4}{*}{0.05} & \multirow{4}{*}{5.9} & 0.05 & 3.3 & 0.1 & 9.2 & 0.25 & 43.5 \\
\hline & & 0.1 & 6.5 & 0.15 & 12.4 & 0.375 & 65.2 \\
\hline & & 0.15 & 9.8 & 0.2 & 15.7 & 0.5 & 87 \\
\hline & & 0.2 & 13 & 0.25 & 18.9 & 0.625 & 108.7 \\
\hline
\end{tabular}

\section{- Influence of temperature}

The variation of temperature affects the polarization of the electrode and, consequently,the deposition potential. The influence of temperature on the chemical composition of deposited layers and cathodic efficiency was studied at $40^{\circ} \mathrm{C}$ and $60^{\circ} \mathrm{C}$.

\section{Experimental work and procedure}

For each experiment, a freshly prepared electrolyte was used. The main components in the bath were metal salts: tin sulphate (as $95.5 \%$ $\mathrm{SnSO}_{4}$ ) and zinc sulphate (as $\mathrm{ZnSO}_{4} * 7 \mathrm{H}_{2} \mathrm{O}$ ), as well as potassium pyrophosphate (as $98 \% \mathrm{~K}_{4} \mathrm{P}_{2} \mathrm{O}_{7}$ ) as a complexing agent. Firstly, a volume of $200 \mathrm{ml}$ de-ionized water was put into a glass beaker placed on a heating plate with a magnetic stirrer. After a heating up to $60^{\circ} \mathrm{C}$, the complexing agent was firstly added in order to be completely dissolved. Then the metal salts were put into the glass beaker and filled to $300 \mathrm{ml}$ with de-ionized water. The prepared electrolyte was finally added to the Hull cell, where the $\mathrm{pH}$ value was adjusted. Finally, the filled electrolyte was mixed with gelatin hydrolysate.The experimental work was performed in the equipment shown in Figure 2. 


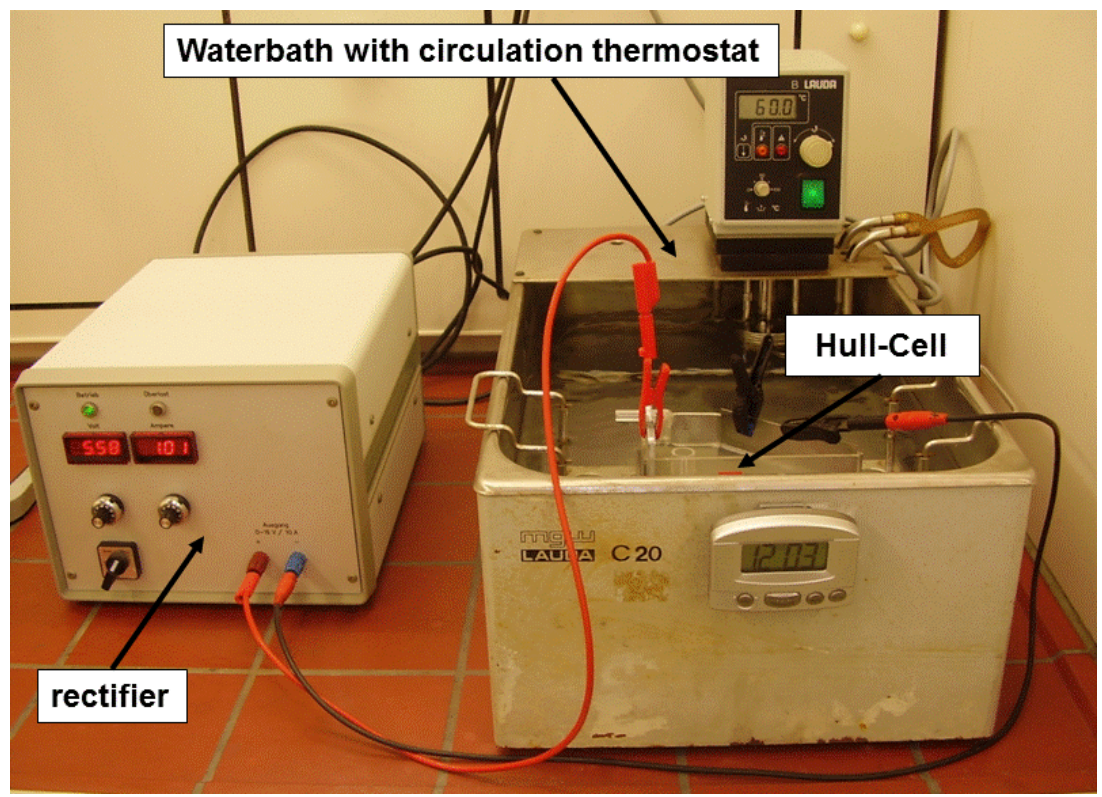

Figure 2 - Electroplating in the Hull cell Puc. 2 - Гальванизация в ячейке Хулла Slika 2 - Galvanizacija u Hulovoj ćeliji

The electroplating parameters in the Hull cell are shown in Table 2.

Table 2 - Electroplating parameters in the Hull cell Таблица 2 - Параметры гальванического покрытия в ячейке Хулла Tabela 2 - Parametri galvanizacije u Hulovoj ćeliji

\begin{tabular}{|l|l|}
\hline \multicolumn{2}{|c|}{ Deposition conditions in the Hull cell } \\
\hline Duration & 20 min \\
\hline Current strenght & $1 \mathrm{~A}$ \\
\hline $\mathrm{pH}$-value & 9.3 \\
\hline Additive & gelatine $1 \mathrm{~g} / \mathrm{l}$ \\
\hline Anode & stainless steel \\
\hline Cathode & carbon steel \\
\hline Flow conditions & without bath stirring \\
\hline
\end{tabular}

The characterization of layers was performed using the X-ray fluorescence analysis XRF, scanning electron microscopy (SEM) and energy dispersive X-ray spectroscopy EDXS. The X-ray fluorescence 
analysis was used for the determination of the thickness and the chemical composition of the prepared $\mathrm{Zn}$-Sn layers. The measurements were performed using aFischerscope X-ray-XDL-device (Company Fischer, Germany). Before the measurement, a required calibration was done using the Fischer standards. The morphology of the deposits and the elemental composition was examined with a ZEISS DSM 982 Gemini scanning electron microscope with an EDX-System, Oxford.

\section{Observations, results and discussion of the $\mathrm{Sn}-\mathrm{Zn}$ electrodeposition in the Hull cell}

During the experimental work, the gas formation was observed on both electrodes. The foam formation on the bath surface was observed during the electroplating process. The experimental design in the Hull cell with the simplified anode and cathode reactions is shown in Figure 3.

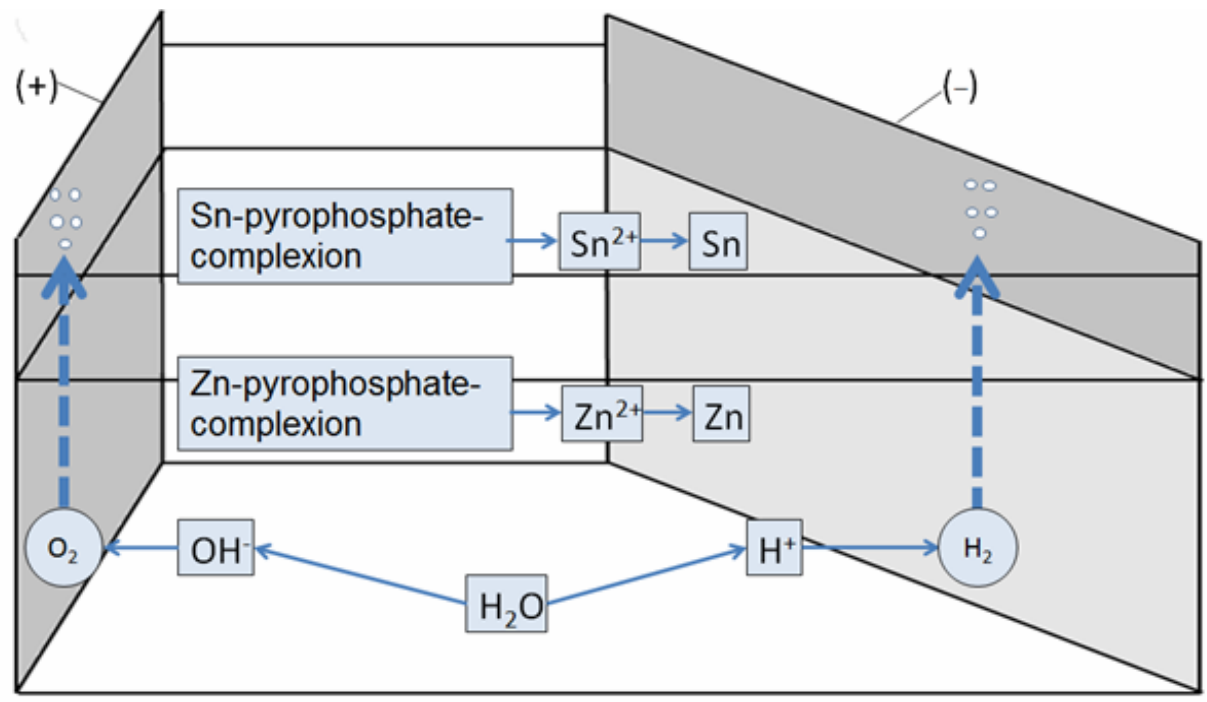

\section{(-) Cathode (steel)}

$$
\mathrm{Sn}^{2+}+2 \mathrm{e}^{-} \rightarrow \mathrm{Sn}
$$$$
\mathrm{Zn}^{2+}+2 \mathrm{e}^{-} \rightarrow \mathrm{Zn}
$$$$
2 \mathrm{H}^{+}+2 \mathrm{e}^{-} \rightarrow \mathrm{H}_{2}
$$

(+) Anode (stainless steel)

$4 \mathrm{OH}^{-} \rightarrow \mathrm{O}_{2}+2 \mathrm{H}_{2} \mathrm{O}+4 \mathrm{e}^{-}$

Figure 3 - Schematic illustration of the anode and cathode reactions in the Hull cell

Puc. 3 - Схема реакций анода и катода в ячейке Хулла

Slika 3 - Šematski prikaz reakcija anode i katode u Hulovoj ćeliji 
All coatings have a bright gray/silver appearance. The influence of the addition of gelatine was investigated, as well. In the absence of gelatine, a gray sponge-like layer was formed in the range of the studied current density (as shown in Figure 4).
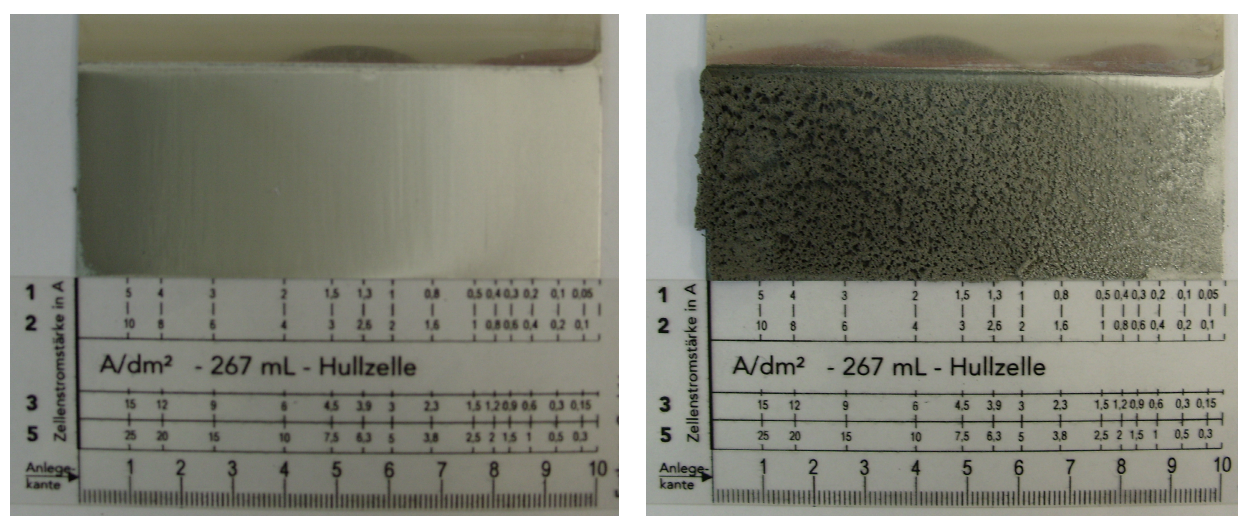

Figure 4 - Illustration of the Sn-Zn layer surface obtained from an electrolyte with $0.05 \mathrm{~mol} / / \mathrm{Zn} ; 0.05 \mathrm{~mol} / \mathrm{I} \mathrm{Sn}$ and $0.25 \mathrm{~mol} / \mathrm{l} \mathrm{K4P2O}$ at $\mathrm{pH}=9.3$ with $1 \mathrm{~g} / \mathrm{l}$ gelatine (left) and in the absence of gelatine

(right) (Working parameters: $1 \mathrm{~A} ; 60^{\circ} \mathrm{C} ; 20 \mathrm{~min}$.)

Puc. 4 - Поверхностный слой покрытия Sn-Zn, полученный из электролита при $0.05 \mathrm{~mol} / / \mathrm{Zn} ; 0.05 \mathrm{~mol} / / \mathrm{Sn}$ и $0.25 \mathrm{~mol} / \mathrm{l} \mathrm{K4P2O}$ при значении $\mathrm{pH}=9.3 \mathrm{c}$ применением $1 \mathrm{~g} / \mathrm{l}$ желатина (слева) и без применения желатина (справа) (рабочие параметры: $1 \mathrm{~A}, 60^{\circ} \mathrm{C} ; 20$ мин.)

Slika 4 - Ilustracija površine sloja $\mathrm{Sn}-\mathrm{Zn}$ dobijena iz elektrolita sa $0.05 \mathrm{~mol} / \mathrm{In}$; $0.05 \mathrm{~mol} / \mathrm{l} \mathrm{Sn}$ i $0.25 \mathrm{~mol} / \mathrm{l} \mathrm{K4P2O}$ pri vrednosti $\mathrm{pH}=9.3 \mathrm{sa} 1 \mathrm{~g} / \mathrm{l}$ želatina (levo) i u odsustvu želatina (desno)

(Radni parametri: $1 \mathrm{~A}, 60^{\circ} \mathrm{C} ; 20 \mathrm{~min}$ )

In Figure 5, a dependency of the chemical composition of the Sn-Zn layers on the electrolyte chemical compositionand the current density is presented. An increase in the current density and the zinc content in the bath led to a decrease of the Sn-content in the deposited Sn-Zn coatings in all cases. 


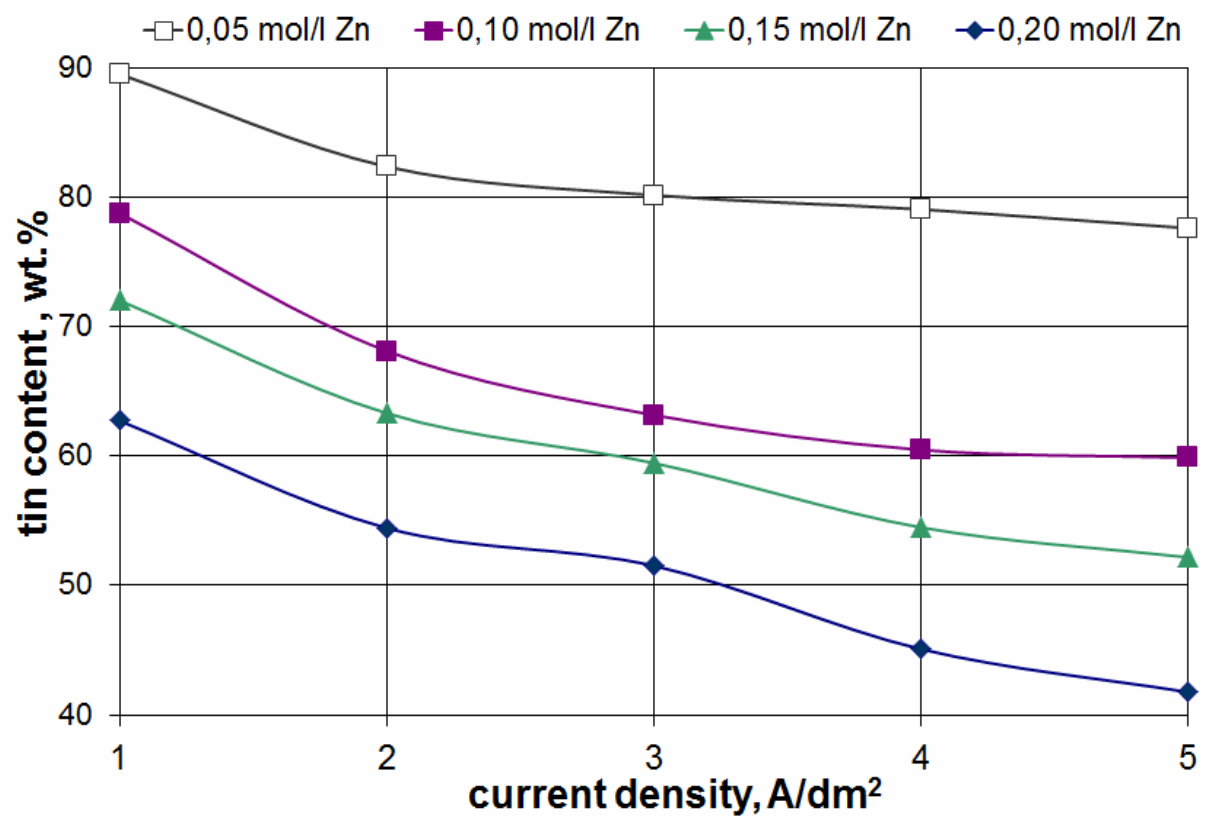

Figure 5 - Tin content in the $\mathrm{Sn}-\mathrm{Zn}$ layers, depending on the zinc content in the bath and current density, at $60^{\circ} \mathrm{C} ; \mathrm{pH}=9.3$ with $0.05 \mathrm{~mol} / \mathrm{l} \mathrm{Sn}$, $\mathrm{c}(\mathrm{P} 2 \mathrm{O} 74-) / \mathrm{c}(\mathrm{Sn} 2++\mathrm{Zn} 2+)=2.5$ and $1 \mathrm{~g} / \mathrm{l}$ gelatine; $1 \mathrm{~A}, 20 \mathrm{~min}$.

Puc. 5 - Содержание олова в покрытии Sn-Zn, зависит от содержания цинка в ванной и плотности токана $60^{\circ} \mathrm{C}$; при значении $\mathrm{pH}=9.3 \mathrm{c} 0.05 \mathrm{~mol} / \mathrm{l} \mathrm{Sn}$ $\mathrm{c}(\mathrm{P} 2 \mathrm{O} 74-) / \mathrm{c}(\mathrm{Sn} 2++\mathrm{Zn} 2+)=2.5$ и 1g/l желатина; 1 A, 20 мин.

Slika 5 - Sadržaj kalaja u slojevima Sn-Zn, zavisno od sadržaja cinka u kupatilu i gustine struje na $60^{\circ} \mathrm{C}$; pri vrednosti $\mathrm{pH}=9.3$ sa $0.05 \mathrm{~mol} / \mathrm{l} \mathrm{Sn}$, $\mathrm{c}(\mathrm{P} 2 \mathrm{O} 74-) / \mathrm{c}(\mathrm{Sn} 2++\mathrm{Zn} 2+)=2.5 \mathrm{i}$ 1g/l želatina; $1 \mathrm{~A}, 20 \mathrm{~min}$.

For nearly all studied current densities, the electroplating at $40^{\circ} \mathrm{C}$ in comparison to that at $60^{\circ} \mathrm{C}$ led to a decreased content of tin in the layer (Figure 6). This is probably connected with a faster dissociation of the zinc pyrophosphate complex compared to that of the tin pyrophosphate complex, at higher temperature. 


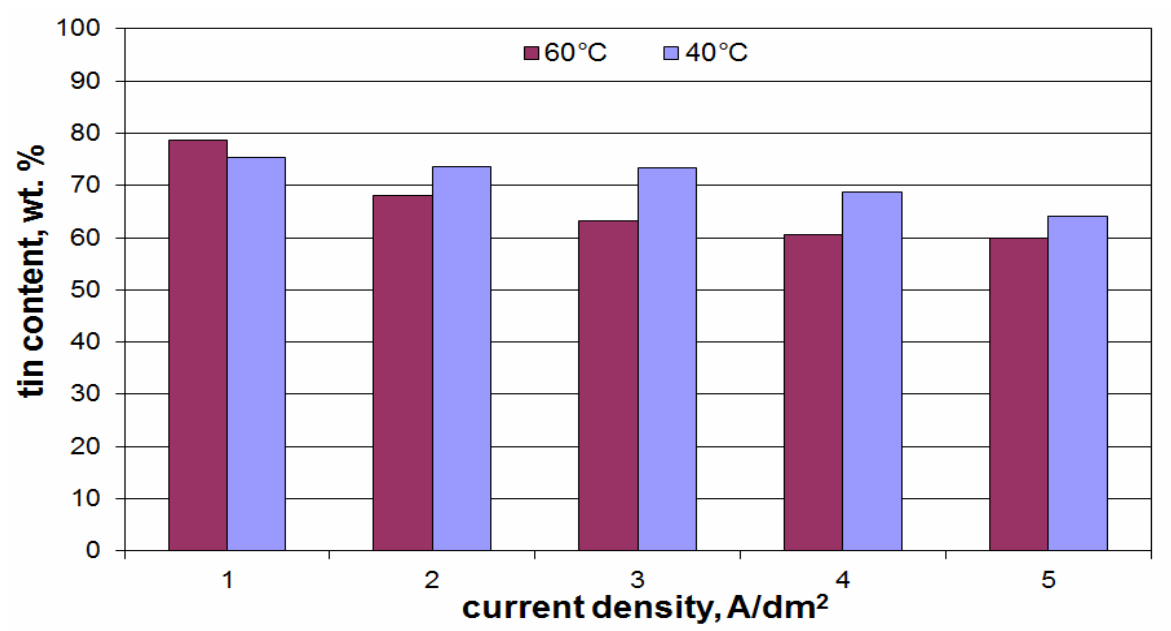

Figure 6 - Tin content in the Sn-Zn-layer depending on temperature and current density (electroplated from an electrolyte with $0.05 \mathrm{~mol} / \mathrm{l} \mathrm{Sn} ; 0.1 \mathrm{~mol} / \mathrm{Zn} ; 0.375 \mathrm{~mol} / \mathrm{l} \mathrm{K} 4 \mathrm{P} 2 \mathrm{O} 7$ and $1 \mathrm{~g} / \mathrm{l}$ gelatine; $\mathrm{pH}=9.3$; Hull cell: $1 \mathrm{~A} ; 20 \mathrm{~min}$.)

Puc. 6 - Содержание олова в покрытии Sn-Zn, зависит от температуры и плотности тока (электрохимическое осаждение из электролита $0.05 \mathrm{~mol} / \mathrm{l} \mathrm{Sn;} 0.1 \mathrm{~mol} / \mathrm{Z} \mathrm{Zn;}$

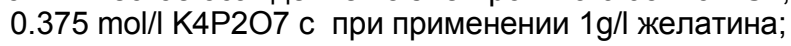
$\mathrm{pH}=9.3$; ячейка Хулла: 1 А, 20 мин.)

Slika 6 - Sadržaj kalaja u Sn-Zn sloju, zavisno od temperature i gustine struje (elektrohemijski nataloženo iz elektrolita sa $0.05 \mathrm{~mol} / \mathrm{l} \mathrm{Sn} ; 0.1 \mathrm{~mol} / / \mathrm{Zn}$;

$0.375 \mathrm{~mol} / \mathrm{K}$ KP2O7 i $1 \mathrm{~g} / \mathrm{l}$ želatina; $\mathrm{pH}=$ 9.3; Hulova ćelija: 1A; $20 \mathrm{~min}$ )

As shown in Figure 7, the deposited layer thickness and, consequently, the current efficiency increased with an increase in temperature from $40^{\circ} \mathrm{C}$ to $60^{\circ} \mathrm{C}$. This behavior can be explained by an inhibition of diffusion of metal ions for discharging from the electrolyte inside the cathode, as well as by a greater reaction overvoltage at a lower temperature, which is caused through a slow dissociation of metal complexes. The increase in the current density led to a reduction in the cathodic current efficiency, which can be caused by the hydrogen favored deposition at higher current densities, probably provoked by the decrease of metal ions to be discharged at the cathode. 


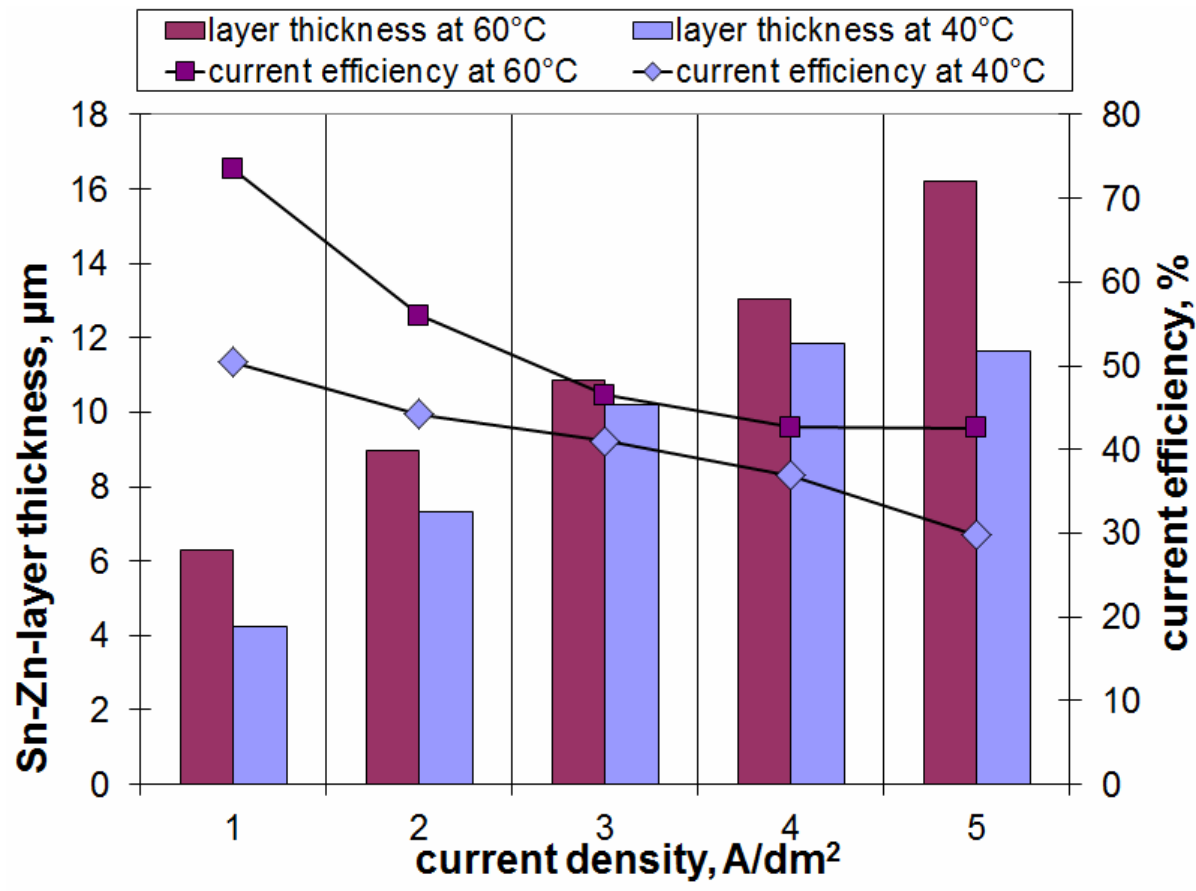

Figure 7 - Cathodic current efficiency and thickness of the Sn-Zn-layer depending on temperature and current density (electroplating from an electrolyte with $0.05 \mathrm{~mol} / \mathrm{l} \mathrm{Sn}$; $0.1 \mathrm{~mol} / \mathrm{l} \mathrm{Zn;} 0.375 \mathrm{~mol} / \mathrm{K} 4 \mathrm{P} 2 \mathrm{O} 7$ and $1 \mathrm{~g} / \mathrm{l}$ gelatine;

$$
\mathrm{pH}=9.3 ; 1 \mathrm{~A} ; 20 \mathrm{~min} \text {.) }
$$

Puc. 7 - Эффрективность катодного тока и толщина Sn-Zn слоя покрытия зависят от температуры и плотности тока (электрохимическое осаждение из электролита

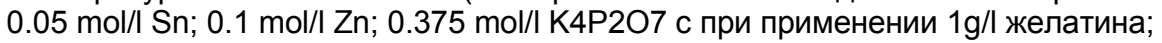
$\mathrm{pH}=9.3 ; 1 \mathrm{~A}, 20$ мин.)

Slika 7 - Efikasnost struje katode i debljina Sn-Zn sloja zavisno od temperature i gustine struje (elektrohemijsko taloženje iz elektrolita sa $0.05 \mathrm{~mol} / / \mathrm{Sn} ; 0.1 \mathrm{~mol} / \mathrm{lZn}$;

$0.375 \mathrm{~mol} / \mathrm{lK} 4 \mathrm{P} 2 \mathrm{O} 7 \mathrm{i} 1 \mathrm{~g} / \mathrm{l}$ želatina; $\mathrm{pH}=9.3 ; 1 \mathrm{~A} ; 20 \mathrm{~min})$

The EDXS analysis of the electrochemically deposited Sn-Zn-layers has confirmed the presence of both metals (Figure 8). 


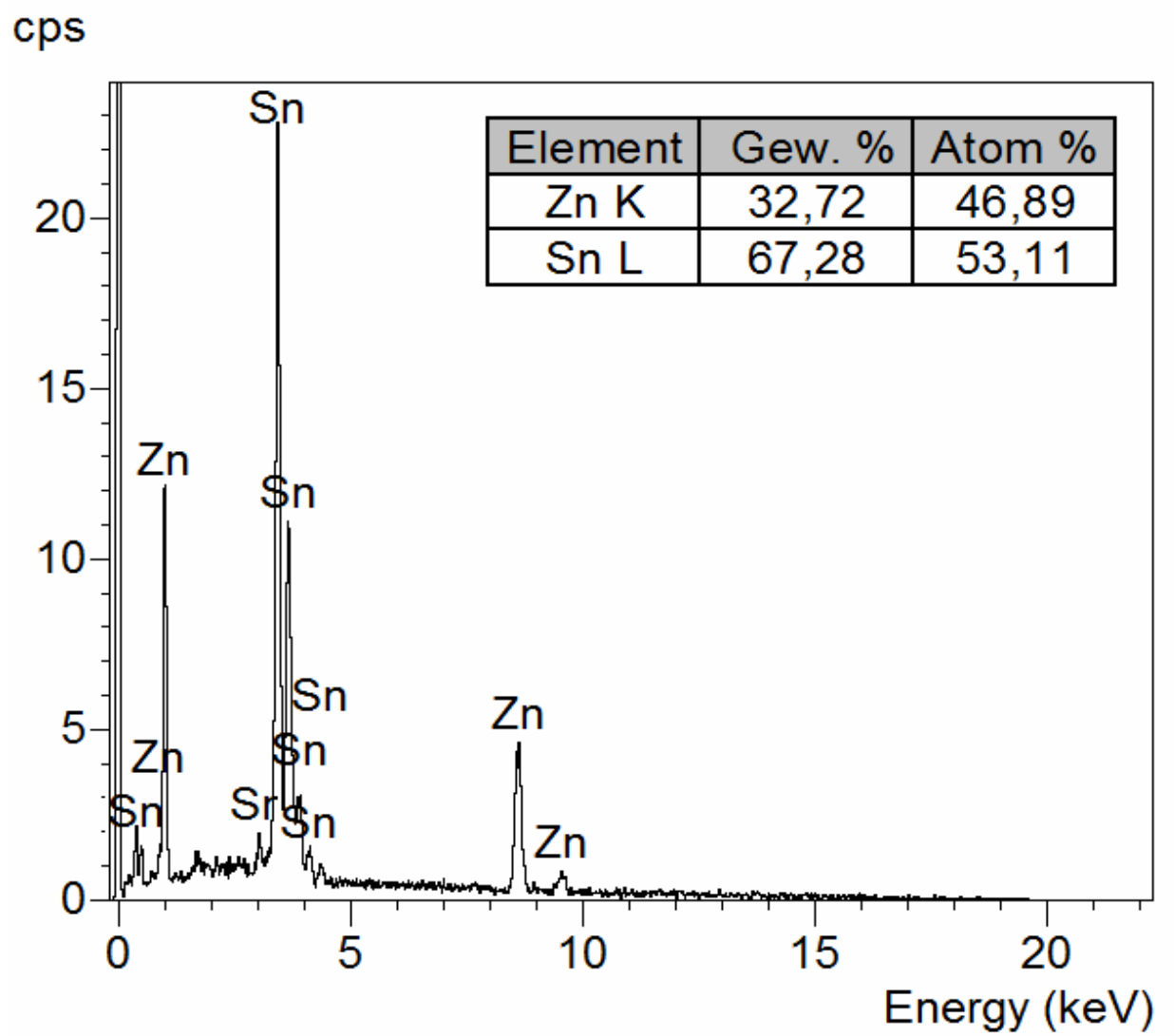

Figure 8 - EDX-spectrum of the Sn-Zn layer electrochemically deposited from an electrolyte with $0.05 \mathrm{~mol} / \mathrm{l} \mathrm{Sn} ; 0.1 \mathrm{~mol} / \mathrm{l} \mathrm{Zn}$;

$0.375 \mathrm{~mol} / \mathrm{l} \mathrm{K} 4 \mathrm{P} 2 \mathrm{O} 7$ and $1 \mathrm{~g} / \mathrm{l}$ gelatine $\left(60^{\circ} \mathrm{C} ; \mathrm{pH}=9.3 ; 20 \mathrm{~min}\right)$ at $2 \mathrm{~A} / \mathrm{dm} 2$

Puc. 8 - EDX спектр Sn-Zn слоев, осажденных при

электрохимическом процессе из электролита с $0.05 \mathrm{~mol} / \mathrm{l} \mathrm{Sn}$;

$0.1 \mathrm{~mol} / \mathrm{Zn}$; $0.375 \mathrm{~mol} / \mathrm{K} \mathrm{K} 4 \mathrm{P} 2 \mathrm{O} 7$ и1 g/l желатина

$\left(60^{\circ} \mathrm{C} ; \mathrm{pH}=9.3 ; 20\right.$ мин.); pri $2 \mathrm{~A} / \mathrm{dm} 2$

Slika 8 - EDX spektar Sn-Zn sloja nataloženog elektrohemijskim procesom iz elektrolita sa $0.05 \mathrm{~mol} / \mathrm{l} \mathrm{Sn;} 0.1 \mathrm{~mol} / \mathrm{l} \mathrm{Zn}$

$0.375 \mathrm{~mol} / \mathrm{K} \mathrm{K} 4 \mathrm{P} 2 \mathrm{O} 7 \mathrm{i} 1 \mathrm{~g} / \mathrm{l}$ želatina

$\left(60^{\circ} \mathrm{C} ; \mathrm{pH}=9.3 ; 20 \mathrm{~min}\right)$ pri $2 \mathrm{~A} / \mathrm{dm} 2$

The SEM images of the Sn-Zn layers, deposited in two different baths at $2 \mathrm{~A} / \mathrm{dm}^{2}$ and $4 \mathrm{~A} / \mathrm{dm}^{2}$ are presented in Figure 9 and Figure 10. The SEM analysis of the Sn-Zn layers shows a fine-grained structure. An increase of the $\mathrm{Zn}$-content in the layer led to the formation of a rough granular structure. 


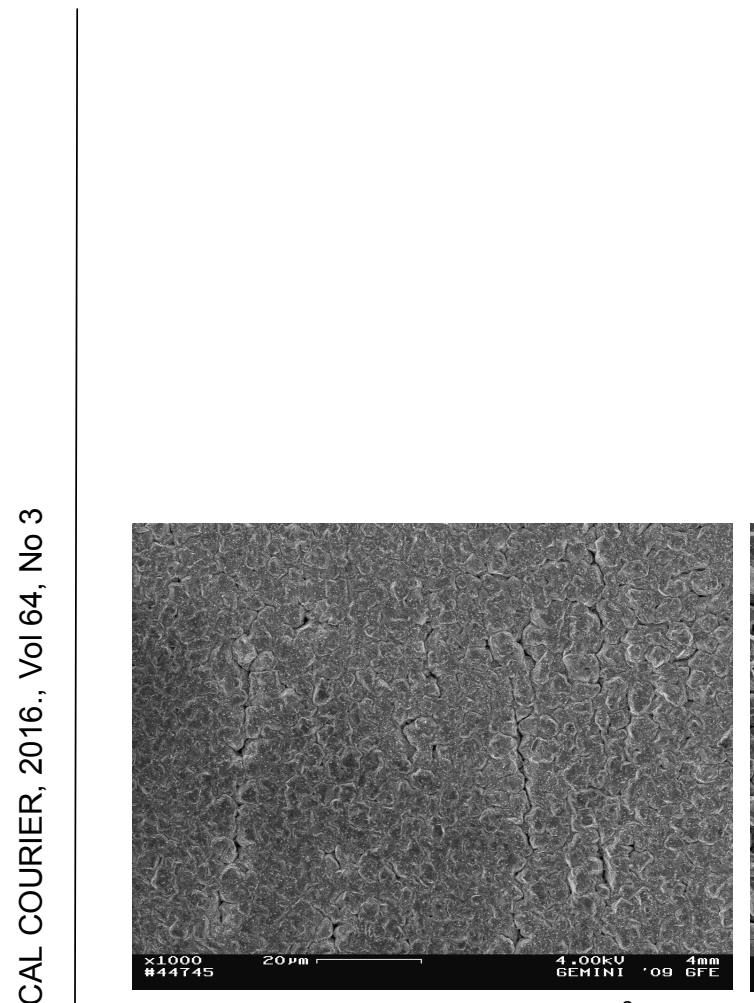

$9 \mu \mathrm{m}$ SnZn33-Layer / 2 A/dm²

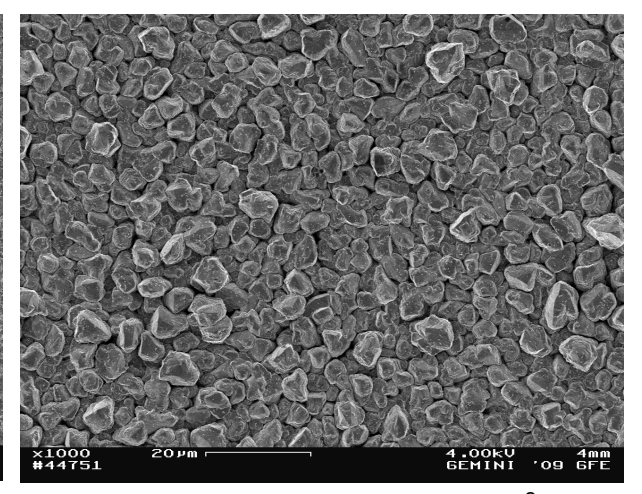

$13 \mu \mathrm{m}$ SnZn42- Layer / 4 A/dm²

Figure 9 - SEM analysis of the Sn-Zn layers obtained from an electrolyte with $0.05 \mathrm{~mol} / / \mathrm{Sn} ; 0.1 \mathrm{~mol} / \mathrm{Z} \mathrm{Zn} ; 0.375 \mathrm{~mol} / \mathrm{l} \mathrm{K} 4 \mathrm{P} 2 \mathrm{O} 7$ and $1 \mathrm{~g} / \mathrm{l}$ gelatine $\left(60^{\circ} \mathrm{C} ; \mathrm{pH}=9.3 ; 20\right.$ min.); magnification: $1.000 \mathrm{x}$

Puc. 9 - SEM анализ Sn-Zn слоев, полученных из электролита с $0.05 \mathrm{~mol} / \mathrm{l} \mathrm{Sn}$; $0.1 \mathrm{~mol} / \mathrm{l} \mathrm{Zn;} 0.375 \mathrm{~mol} / \mathrm{l} \mathrm{K4P2O7} \mathrm{и} 1 \mathrm{~g} / \mathrm{l}$ желатина $\left(60^{\circ} \mathrm{C} ; \mathrm{pH}=9.3 ; 20\right.$ мин.); масштаб увеличения: $1.000 \mathrm{x}$

Slika 9 - SEM analiza Sn-Zn slojeva dobijenih iz elektrolita sa $0.05 \mathrm{~mol} / \mathrm{l} \mathrm{Sn}$; $0.1 \mathrm{~mol} / \mathrm{l} \mathrm{Zn} ; 0.375 \mathrm{~mol} / \mathrm{l} \mathrm{K} 4 \mathrm{P} 2 \mathrm{O} 7 \mathrm{i} 1 \mathrm{~g} / \mathrm{l}$ želatina $\left(60^{\circ} \mathrm{C} ; \mathrm{pH}=9.3 ; 20 \mathrm{~min}\right.$.); uvećanje: $1.000 \mathrm{x}$

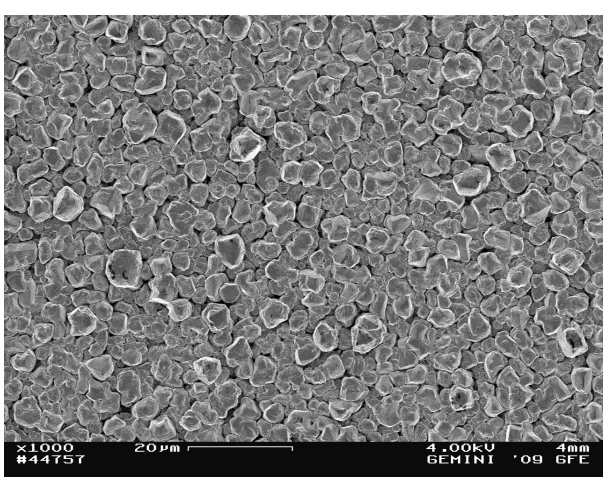

$9 \mu \mathrm{m}$ SnZn41-Layer / $2 \mathrm{~A} / \mathrm{dm}^{2}$

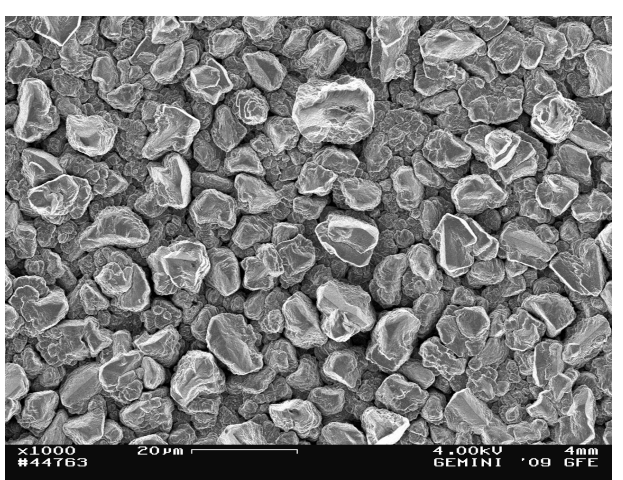

$15 \mu \mathrm{m}$ SnZn62-Layer / $4 \mathrm{~A} / \mathrm{dm}^{2}$

Figure 10 - SEM analysis of the Sn-Zn layers obtained from an electrolyte with $0.05 \mathrm{~mol} / \mathrm{l}$ $\mathrm{Sn} ; 0.2 \mathrm{~mol} / \mathrm{Zn}$; $0.625 \mathrm{~mol} / / \mathrm{K} 4 \mathrm{P} 2 \mathrm{O} 7$ and $1 \mathrm{~g} / \mathrm{l} \mathrm{Gelatine}\left(60^{\circ} \mathrm{C} ; \mathrm{pH}=9.3 ; 20 \mathrm{~min}\right)$; magnification: $1.000 \mathrm{x}$

Puc. 10 - SEM анализ Sn-Zn слоев, полученных из электролита с $0.05 \mathrm{~mol} / \mathrm{l} \mathrm{Sn}$; $0.2 \mathrm{~mol} / / \mathrm{Zn} ; 0,625 \mathrm{~mol} / / \mathrm{K} 4 \mathrm{P} 2 \mathrm{O} 7$ и $1 \mathrm{~g} / \mathrm{l}$ желатина $\left(60^{\circ} \mathrm{C} ; \mathrm{pH}=9.3 ; 20\right.$ мин.); масштаб увеличения: $1.000 \mathrm{x}$

Slika 10 - SEM analiza Sn-Zn slojeva dobijenih iz elektrolita sa $0.05 \mathrm{~mol} / \mathrm{Sn}$;

$0.2 \mathrm{~mol} / / \mathrm{Zn} ; 0,625 \mathrm{~mol} / \mathrm{K} 4 \mathrm{P} 2 \mathrm{O} 7 \mathrm{i} 1 \mathrm{~g} / \mathrm{l}$ želatina $\left(60^{\circ} \mathrm{C} ; \mathrm{pH}=9.3 ; 20 \mathrm{~min}\right.$.); uvećanje: $1.000 \mathrm{x}$

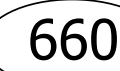


A SnZn28layer was analyzed using the EDX analysis and a mapping function. Figure 11 shows a SEM image in gray. The element distribution images are shown in different colors: Zn-(red) and Sn-(green). The constituent parts are identified in the common layer in accordance wththeir ratios. The mixed elemental map shows that the layer is composed of a zinc layer located at the bottom and of many granules rich in tin. During the electrodeposition, zinc is preferentially deposited at the beginning, which is caused probably by an irregular co-deposition mechanism.

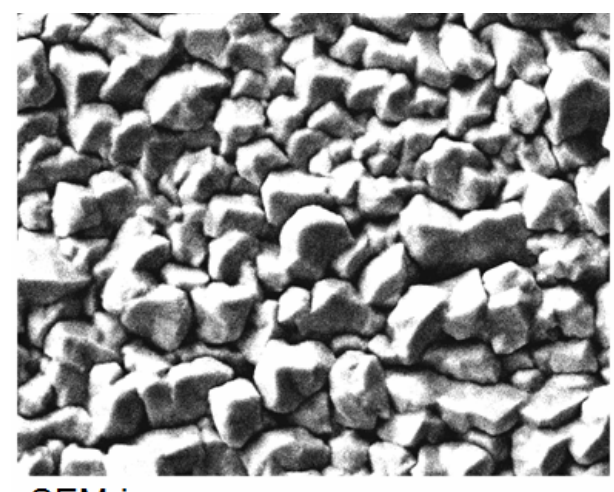

SEM-image

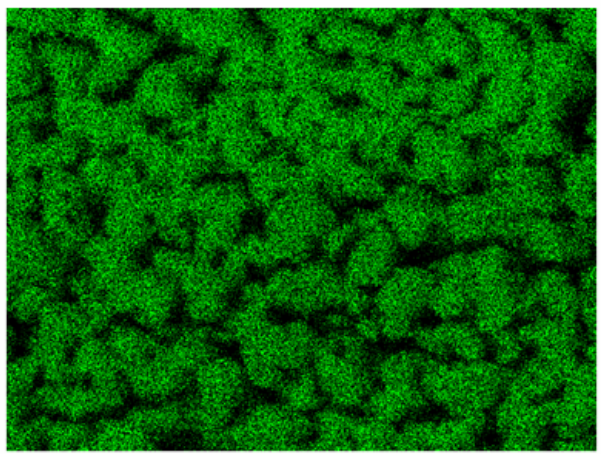

Sn La1

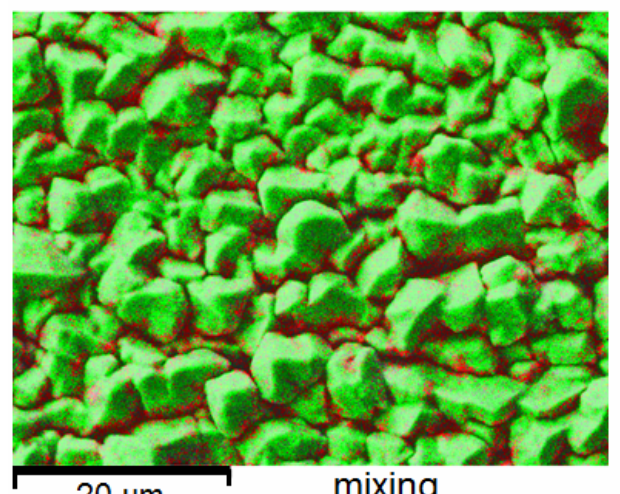

$20 \mu \mathrm{m}$

mixing

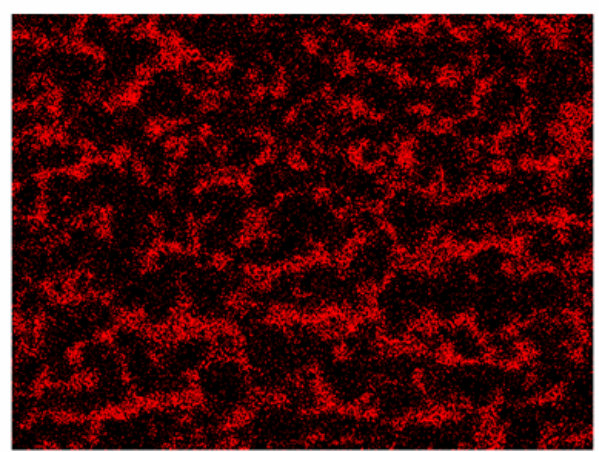

Zn Ka1

Figure 11 - SEM image and elemental maps in a SnZn28- layer (6 $\mu \mathrm{m})$

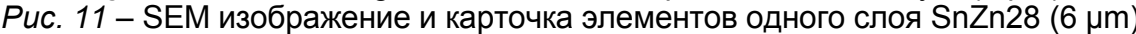
Slika 11 - SEM fotografija i mape elemenata u jednom sloju SnZn28 $(6 \mu \mathrm{m})$ 


\section{Electrochemical studies of the electrodeposition of Sn-Zn layers}

The most important aim of the electrochemical investigations is a detailed analysis of different partial processes in order to arrange and understand them. The electrochemical behavior is studied using the following methods:

- Linear-Sweep-Voltammetry (LSV)

- Cyclovoltammogrammetry /CV)

\section{Experimental setup for measurements}

The experimental setup for the recording of the current-potential curves contains the following components (as shown in Figure 12):

- electrochemical three-electrode cell

- waterbath with thermostat

- potentiostat (typ: Iviumsoft)

- electronic dataacquisition

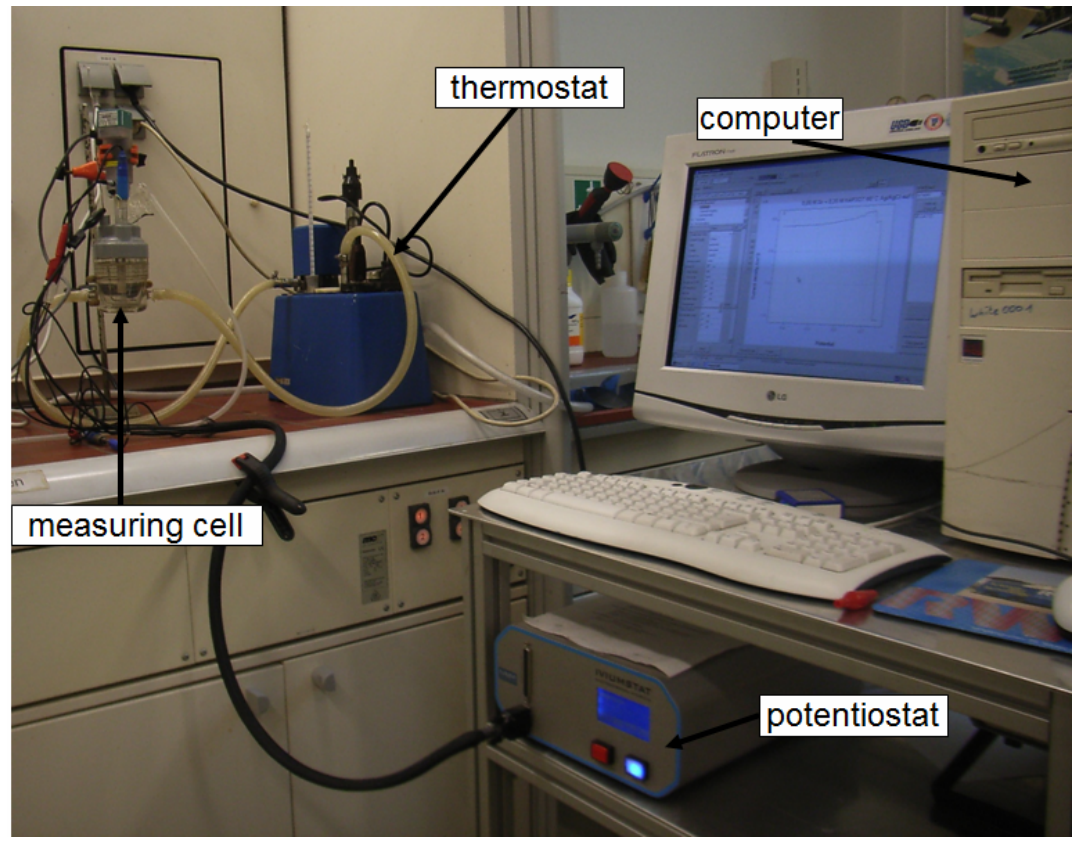

Figure 12 - Experimental setup for the electrochemical measurement Puc. 12 - Экспериментальное оборудование для электрохимических измерений Slika 12 - Eksperimentalna oprema za elektrohemijsko merenje 
The electrochemical cell consists of a double walled glass beaker of $100 \mathrm{ml}$ volume, connected with a waterbath and covered by a plastic lid. The five bore holes on the lid are required for the positioning of three electrodes, a thermometer and an injection tube for gas. The usedmeasuringcellisshown in Figure 13.
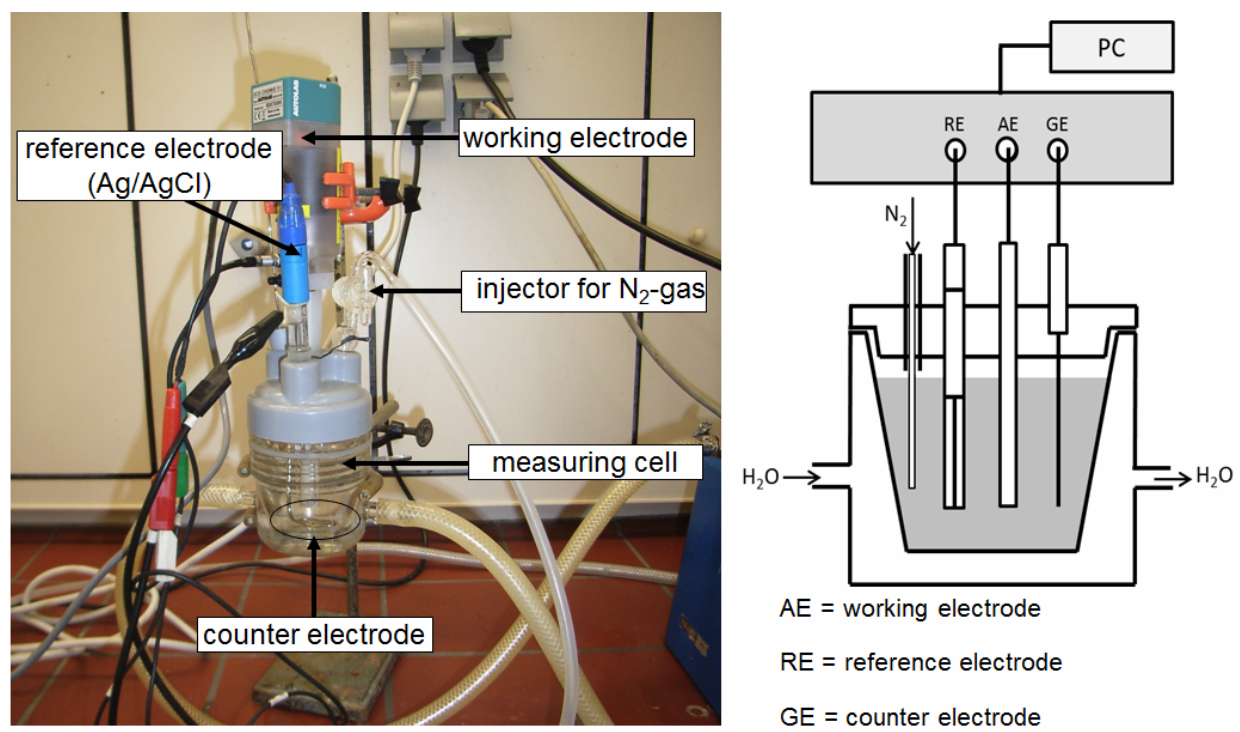

Figure 13 - Temperature-controlled $100 \mathrm{ml}$ glass measuring cell with a three electrode setup

Puc. 13 - Стеклянная измерительная ячейка - $100 \mathrm{ml} \mathrm{c}$ контролируемой температурой и тремя электродами

Slika 13 - Staklena merna ćelija od $100 \mathrm{ml}$ sa kontrolisanom temperaturom i povezane tri elektrode

In the voltammetric studies, a copper disc was used as a working electrode (surface area $0,785 \mathrm{~cm}^{2}$ ). The working electrode potentials were referred to as an $\mathrm{Ag} / \mathrm{AgCl}$ electrode. The counter electrode was a platinum rod.

The cathodic current- potential curves of tin, zinc, and tin-zinc deposition from a pyrophosphate electrolyte are shown in Figure 14. In the mixed Sn-Zn electrolyte, the deposition began at a more positive potential in comparison with the electrolytes containing only one metal. 


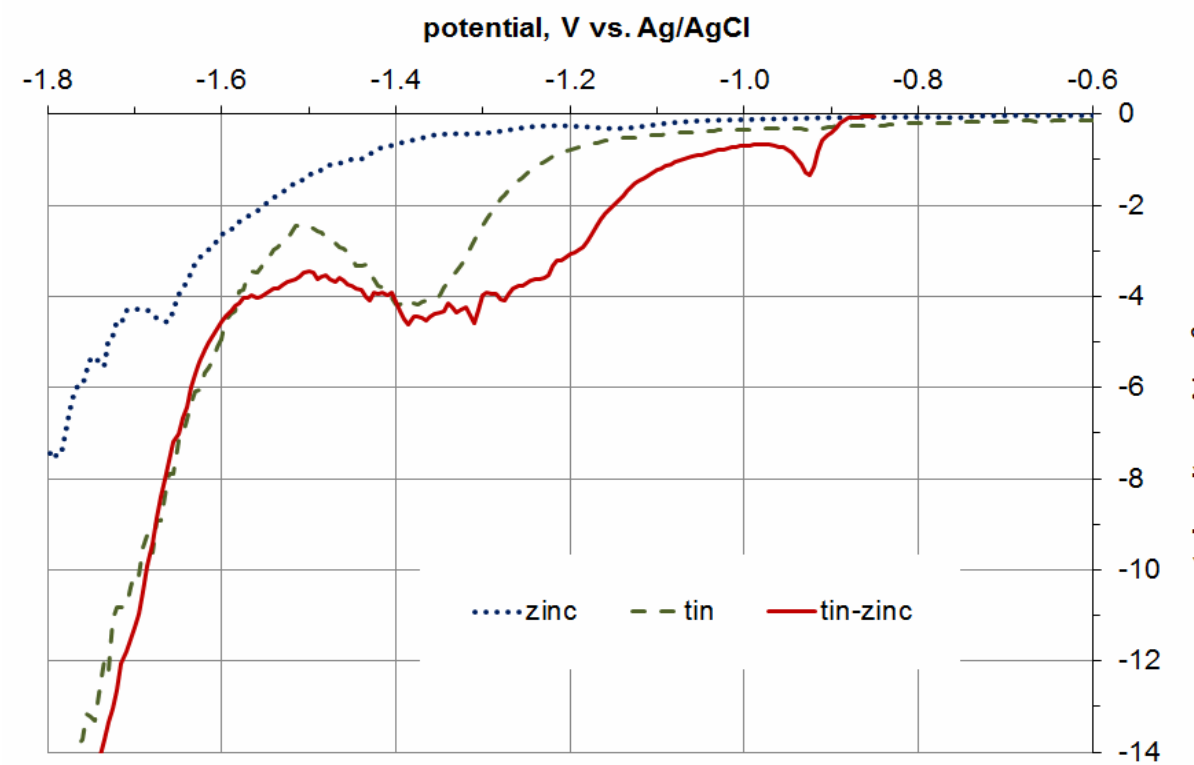

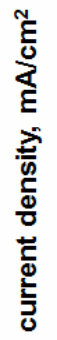

Figure $14-$ Polarisation curves of tin, zinc- and tin-zinc deposition on copper at $60^{\circ} \mathrm{C}$ and $\mathrm{pH}=9.3 ; \mathrm{v}=1 \mathrm{mV} / \mathrm{s}(0.05 \mathrm{~mol} / \mathrm{l} \mathrm{Me}+0.25 \mathrm{~mol} / \mathrm{l} \mathrm{K4P2O}$ with $1 \mathrm{~g} / \mathrm{l}$ gelatine $)$

Puc. 14 - Поляризационные кривые осажденного олова, цинка и сплава олово-цинк на меди при $60^{\circ} \mathrm{C}$, со значением $\mathrm{pH}=9.3 ; \mathrm{v}=1 \mathrm{mV} / \mathrm{s}(0.05 \mathrm{~mol} / / \mathrm{Me}+0.25 \mathrm{~mol} / \mathrm{l}$ K4P2O7 с применением $1 \mathrm{~g} / \mathrm{l}$ желатина

Slika 14 - Polarizacione krive nataloženog kalaja, cinka i legure kalaja i cinka na bakru na $60^{\circ} \mathrm{C}$ pri vrednosti $\mathrm{pH}=9.3 ; \mathrm{v}=1 \mathrm{mV} / \mathrm{s}(0.05 \mathrm{~mol} / \mathrm{l} \mathrm{Me}+0.25 \mathrm{~mol} / \mathrm{l} \mathrm{K} 4 \mathrm{P} 2 \mathrm{O} 7$ sa $1 \mathrm{~g} / \mathrm{l}$ želatina

The cyclovoltammetry allows a determination of electrode kinetics in a wide potential range using only one measurement. All measurements were performed at a scan rate of $5 \mathrm{mV} / \mathrm{s}$, scanning towards negative potentials. In Figure 15, the cyclic voltammograms obtained from pyrophosphate electrolytes are given. After comparing the single diagrams for pure zinc, pure tin and the Sn-Zn alloy, it can be concluded that, in the case of a co-deposition, the reduction peaks for both alloying elements were shifted about $100 \mathrm{mV}$ to the positive potential value in comparison to the single deposition. This indicates that, in a mixed electrolyte, a strong interdependency happens between the adsorbed zinc and tin species. 


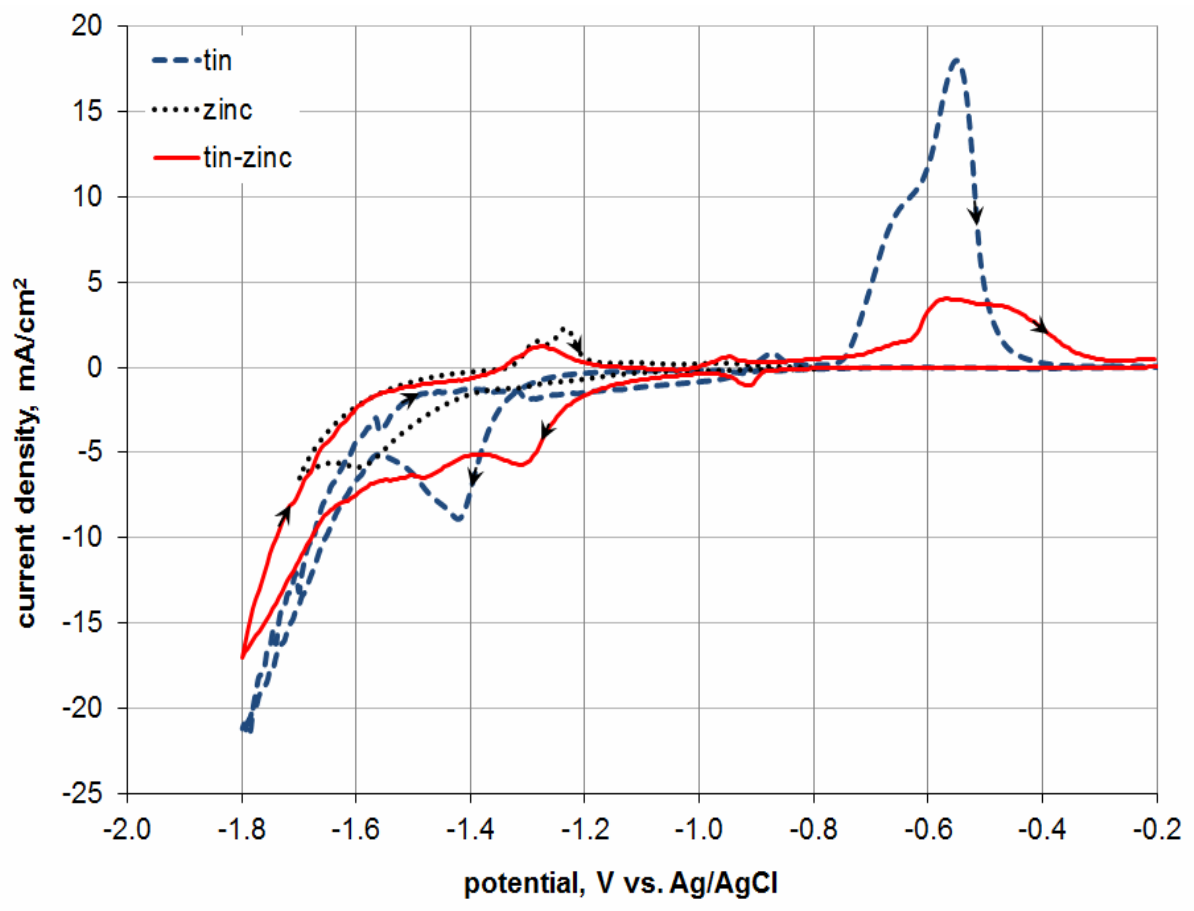

Figure 15 - Cyclic voltammogramms of zinc-, tin and tin-zinc electrodeposition in a pyrophosphate electrolyte with $0.05 \mathrm{~mol} / \mathrm{Z} \mathrm{Zn}$ or/and $0.05 \mathrm{~mol} / \mathrm{l} \mathrm{Sn}, 0.25 \mathrm{~mol} / \mathrm{l} \mathrm{K4P2O}$ and $1 \mathrm{~g} / \mathrm{l}$ gelatine at $60^{\circ} \mathrm{C}$ and $\mathrm{pH}=9.3 ; \mathrm{AE}$ : copper; $\mathrm{v}=5 \mathrm{mV} / \mathrm{s}$.

The arrows indicate the scan direction.

Puc. 15 - Циклическая вольтамперограмма электрохимических осаждений цинка, олова и сплава цинк-олово в пирофоссратном электролиту с $0.05 \mathrm{~mol} / \mathrm{l} \mathrm{Zn} \mathrm{и/или} 0.05$ $\mathrm{mol} / / \mathrm{Sn}, 0.25 \mathrm{~mol} / / \mathrm{K} 4 \mathrm{P} 2 \mathrm{O} 7$ и $1 \mathrm{~g} / \mathrm{l}$ желатина при $60^{\circ} \mathrm{C}$ и pH=9.3; AE: медь; $\mathrm{v}=5 \mathrm{mV} / \mathrm{s}$. Стрелка обозначает направление сканирования.

Slika 15 - Ciklični voltamogrami elektrohemijski nataloženog cinka, kalaja i legure cinka i kalaja u pirofosfatnom elektrolitu su $0.05 \mathrm{~mol} / \mathrm{l} \mathrm{Zn} \mathrm{i/ili} 0.05 \mathrm{~mol} / \mathrm{l} \mathrm{Sn}, 0.25 \mathrm{~mol} / / \mathrm{K} 4 \mathrm{P} 2 \mathrm{O} 7 \mathrm{i}$ $1 \mathrm{~g} / \mathrm{l}$ želatinana $60^{\circ} \mathrm{C}$ i $\mathrm{pH}=9.3 ; \mathrm{AE}$ : bakar; $\mathrm{v}=5 \mathrm{mV} / \mathrm{s}$. Strelica označava pravac skeniranja.

\section{Electrochemical behavior of the $\mathrm{Sn}-\mathrm{Zn}$ layers in 3 wt. $\% \mathrm{NaCl}$}

The corrosion behavior of the Sn-Zn layers with different chemical compositions was studied by means of potentiodynamic polarization tests (Wang, Pickering, \&Weil, 2004, pp.34-37). An evaluation of the corrosion parameters with the aid of the Tafel extrapolation method has shown that all investigated $\mathrm{Sn}-\mathrm{Zn}$ layers can be utilized for the protection of steel 
substrate in chloride-containing media as a sacrificial anode (Taguchi, Bento \&Mascaro, 2008, pp.727-733)

Between the three Sn-Zn layers, the layer with 28.5 wt. \% zinc has exhibited the lowest corrosion rate (Table 3).

Table 3 - Comparison of the corrosion parameters of Sn-Zn layers obtained from different pyrophosphate baths (corrosion medium: $3 \mathrm{wt}$ \% $\mathrm{NaCl}$ solution at room temperature) Таблица 3 - Сравнение коррозийных параметров покрытия из сплавов цинка и олова, полученных из различных пирофосфатных ванн (коррозийная среда: 3 вес \% раствор $\mathrm{NaCl}$ при комнатной температуре)

Tabela 3 - Poređenje korozivnih parametara slojeva legure cinka i kalaja dobijenih iz različitih pirofosfatnih kupatila (korozivna sredina: 3 tež\% rastvor $\mathrm{NaCl}$ na sobnoj temperaturi)

\begin{tabular}{|c|c|c|c|c|}
\hline & Steel & SnZn 13.5\% & SnZn 28,5\% & SnZn 48\% \\
\hline corrosion potential, $\mathrm{V}_{\text {SCE }}$ & -0.781 & -1.159 & -1.137 & -1.18 \\
\hline corrosion current density, A/cm & $4.92 \mathrm{E}-07$ & $2.92 \mathrm{E}-06$ & $2.35 \mathrm{E}-06$ & $5.43 \mathrm{E}-06$ \\
\hline
\end{tabular}

\section{Conclusions}

This work studied the electrodeposition of Sn-Zn layers from a weak alkaline sulphate-pyrophoshate electrolyte. The deposition of the layers was performed in the Hull cell. The electrochemical characterization was performed in a measuring cell with a three electrode setup employing Linear-Sweep-Voltammetry (LSV) und Cyclovoltammetry (CV). The corrosion behavior of the deposited Sn-Zn-layers was investigated using the potentiodynamic method in order to determine the current-potential curves.

The most important findings are presented below:

- During electroplating, a gas formation was observed on both electrodes. All coatings had a gray/silver bright look with a fine striation.

- The chemical composition of deposits varied depending on different bath compositions and current densities.

- An increase in current density and zinc content in the bath increased the content of zinc in the deposited Sn-Zn layer. For example, an increase in current density from $1 \mathrm{~A} / \mathrm{dm}^{2}$ to $5 \mathrm{~A} / \mathrm{dm}^{2}$ at the same chemical composition of the bath led to an increase of about $20 \mathrm{wt}$ \% of zinc in the layer. At the same current density, an increase of tin content from 30 to 65 wt. \% in the bath led again to an increase of tin content of about 35 wt \% in the layer.

- An increase of current density led to a decrease of current efficiency at all studied bath compositions. 
- The SEM analysis of the Sn-Zn layers showed a dense, finegrained structure. An increase of the zinc content influenced the formation of a rough crystalline arrangement.

- In the absence of gelatin-hydrolysate, the sponged structure was formed, which confirms that the limited current density was overpassed. An addition of colloid admixture led to a formation of smooth layers.

- In the mixed Sn-Zn electrolyte, the deposition began at the more positive potential in comparison to that for each single metal, which means that a strict interdependence exists between absorbed tin and zinc species. An increase of zinc in the bath led to a replacement of the deposition curves again to the negative values of potential.

- The obtained results of electrochemical investigations reveal that the corrosion potential of all studied Sn-Zn alloys was more negative than the one for the steel sample. Therefore, it is possible to use all three investigated tin-zinc alloys as an anode for protection of steel substrate in a chloride medium.

At the end of this conclusion, it might be pointed out that $\mathrm{Sn}-\mathrm{Zn}$ layers with good corrosion characteristics can be deposited from a sulfate-pyrophosphate bath (Stopic, 2015, pp.101). Using different characterization techniques (Hull cell, RFA-, SEM- and EDX-analysis, Linearsweep- und Cyclovoltammetry) enables a complete study of very important parameters and their interdependency (Dubent, et al. 2007, pp.146-152).

\section{References}

Andrle, C., \&Jelinek, T.W. 2007. Hull-Zelle zur Untersuchung von galvanischen Elektrolyten. Eugen G. Leuze Verlag. ISBN 3-87480-224-8.

Ashiru, O.A., \&Shirokoff, J. 1996. Electrodeposition and characterisation of tin-zinc alloy coatings. Applied Surface Science,103, pp.159-169.

Despic, A.R., \&Jovic, V.D. 1996. Formation of Metallic Materials of Desired Structure and Properties by Electrochemical Deposition. Materials Science Forum, 214, pp.239-248.

Dubent, S., de Petris-Wery, M., Saurat, M., \&Ayedi, H.F. 2007.Composition control of tin-zinc electrodeposits through means of experimental strategies. Materials Chemistry and Physics, 104, pp.146-152.

Stopic, M. 2015. Abscheidung, Characterisierung und Korrosions untersuchungen von galvanischen Zinn-Zink-Schichten aus Pyrophosphatbädern. Shaker Verlag GmbH.

Taguchi, A.S., Bento, F.R., \&Mascaro, L.H. 2008.Nucleation and Growth of Tin-Zinc Electrodeposits on a Polycrystalline Platinum Electrode in Tartaric Acid. J. Braz. Chem. Soc., 19(4), pp.727-733.

Vitkova, S., Ivanova, V., \&Raichevsky, G. 1996.Electrodeposition of low tin content zinc-tin alloys. Surface and Coatings Technology, 82, pp.226-231.

Wang, K., Pickering, H.W., \& Weil, K.G. 2004. Corrosion Behavior Of Electroplated Tin-Zinc Coatings. Plating \& Surface Finishing, pp.34-37. January. 
ЭЛЕКТРОХИМИЧЕСКИЕ ОСАЖДЕНИЯ, КЛАССИФИКАЦИЯ И ИСПЫТАНИЯ КОРРОЗИИ ПОКРЫТИЯ НА ОСНОВЕ ЦИНКА И ОЛОВА, ОБРАЗОВАННОЙ НА ПОВЕРХНОСТИ ПИРОФОСФАТНОЙ ВАННЫ

\author{
Милена Д. Стопич ${ }^{a}$, Бернд Г. Фридрих ${ }^{6}$ \\ ${ }^{\mathrm{a}}$ MEAB Chemie Technik $\mathrm{GmbH}$, Aachen, Germany, \\ ${ }^{\sigma}$ IME Process Metallurgy and Metal Recycling, \\ RWTH Aachen University, Germany
}

ОБЛАСТЬ: химические технологии, электрохимия, коррозия ВИДСТАТЬИ: оригинальная научная статья ЯЗЫКСТАТЬИ: английский

Резюме:

Покрытия из олова и цинка являются потенциальным аналогом токсичного кадмия для антикоррозийной защиты.

Покрытия на основе сплава олово-цинк являются отличной антикоррозийной защитой для стальных изделий. При осаждениев качестве барьерного слоя используется олово, а в качестве гальванического защитного слоя-цинк.

Покрытия на основе олово-цинк первоначально применялись для защиты шасси электрооборудования и электронной техники, а также для защиты критических автодеталей, например,тормозной системы.

В данной работе приведены результаты успешного применения сплава на основе олово-цинк в качестве покрытия пирофросфатных ванн.

Соответствующие пропорции сплава олова и цинка определены составом ванны и операционных параметров нанесения каждого отдельного слоя покрытия. Для электрохимических испытаний применялась ячейка из трех электродов.

Испытания механизма электрохимического осаждения Sn-Zn покрытия проводились линейной и циклической вольтаммограммой. Параметры коррозии, включая влияние потенциал-время, коррозийный потенциал и плотность тока коррозии электрохимические осаждения сплава олово-цинк различного состава тестировались в растворе с содержанием $3 \% \mathrm{NaCl}$.

Коррозийная стойкость зависит от состава отдельных слоев. Слой, содержащий Sn-28Zn отличается лучшими антикоррозийными свойствами.

Ключевые слова: электрохимическое осаждение, коррозия, гальванические покрытия, цинк, олово. 
ELEKTROHEMIJSKO TALOŽENJE, KARAKTERIZACIJA I ISPITIVANJA KOROZIJE SLOJEVA NA BAZI CINKA I KALAJA NASTALIH TALOŽENJEM IZ PIROFOSFATNIH KUPATILA

Paper received on / Дата получения работы / Datum prijema članka: 26. 03. 2016.

Milena D. Stopić ${ }^{\mathrm{a}}$, Bernd G. Friedrich ${ }^{\mathrm{b}}$

${ }^{a}$ MEAB Chemie Technik GmbH, Aachen, Germany,

${ }^{b}$ IME Process Metallurgy and Metal Recycling, RWTH Aachen University, Germany

OBLAST: hemijske tehnologije, elektrohemija, korozija

VRSTA ČLANKA: originalni naučni članak

JEZIK CLLANKA: engleski

\section{Sažetak:}

Slojevi kalaja i cinka označeni su kao potencijalna alternativa za otrovni kadmijum korišćen kao zaštitni korozivni sloj. Slojevi na bazi legure kalaj-cinka poseduju izuzetnu korozivnu zaštitu za čelik, kombinujući zaštitu korišćenog kalaja kao barijere zajedno sa galvanskom zaštitom od cinka. Prevlake na bazi kalaja i cinka prvobitno su korišćene za šasije električnih i elektronskih aparatura ili za kritične delove $i$ kočione sisteme. $U$ ovom radu legure na bazi kalaja i cinka uspešno su proizvedene iz baznih pirofosfatnih kupatila. Proces izdvajanja metala daje kompaktan i finozrnasti deposit. Željeni odnosi cinka i kalaja u nanesenoj leguri odredjeni su od sastava kupatila i operacionih parametara tokom izdvajanja slojeva. Sistem od tri elektrode korišćen je za elektrohemijska istraživanja. Mehanizam elektrohemijskog taloženja Sn-Zn sloja ispitivan je linearnom i cikličnom voltametrijom. Parametri korozije, uključujući zavisnosti potencijalvreme, korozivni potencijal i gustinu struje korozije elektrohemijski taložene kalaj-cink legure različitih sastava izvođeni su u rastvoru koji sadrži 3\% $\mathrm{NaCl}$. Korozivna otpornost zavisi od sastava izdvojenog sloja, a sloj koji sadrži Sn-28 Zn pokazao je najbolja antikorozivna svojstva.

Ključne reči: elektrohemijsko taloženje, korozija, galvanski slojevi, cink, kalaj.

Manuscript corrections submitted on / Дата получения исправленной версии работы / Datum dostavljanja ispravki rukopisa: 10. 04. 2016.

Paper accepted for publishing on / Дата окончательного согласования работы / Datum konačnog prihvatanja članka za objavljivanje: 12. 04. 2016.

(C) 2016 The Authors. Published by Vojnotehnički glasnik / Military Technical Courier (www.vtg.mod.gov.rs, втг.мо.упр.срб). This article is an open access article distributed under the terms and conditions of the Creative Commons Attribution license (http://creativecommons.org/licenses/by/3.0/rs/).

(c) 2016 Авторы. Опубликовано в "Военно-техническийвестник / Voinnotehnički glasnik / Military Technical Courier" (www.vtg.mod.gov.rs, втг.мо.упр.срб). Данная статья в открытом доступе и распространяется в соответствии с лицензией "Creative Commons" (http://creativecommons.org/licenses/by/3.0/rs/).

(C) 2016 Autori. Objavio Vojnotehnički glasnik / Military Technical Courier (www.vtg.mod.gov.rs, втг.мо.упр.срб). Ovo je članak otvorenog pristupa i distribuira se u skladu sa Creative Commons licencom (http://creativecommons.org/licenses/by/3.0/rs/).

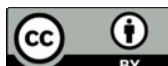

